\title{
Autobiographies in Preservice Teacher Education: \\ A Snapshot Tool for Building a Culturally Responsive Pedagogy
}

\author{
AnnMarie Alberton Gunn, Ph. D. \\ University of South Florida St. Petersburg \\ U. S. A. \\ Susan V. Bennett, Ph. D. \\ University of Mississippi \\ U. S. A. \\ Linda Shuford Evans, Ph. D. \\ Kennesaw State University \\ U. S. A. \\ Barbara J. Peterson, M. A. \\ University of South Florida Tampa \\ U. S. A. \\ James L. Welsh, M. A. \\ University of South Florida Tampa \\ U. S. A.
}

Many scholars have made the call for teacher educators to provide experiences that can lead preservice teachers to embrace a culturally responsive pedagogy. We investigated the use of brief autobiographies during an internship as a tool (a) for preservice teachers to examine their multidimensional culture; and (b) for teacher educators to assess preservice teachers' developing understandings about cultural responsive pedagogy and then further design curriculum to enhance these understandings. Using qualitative methods, we analyzed the preservice teachers' $(\mathrm{N}=24)$ autobiographies and an interview with the professor of this course. Based on the findings of this study, we suggest teacher educators need to develop experiences and opportunities that will enable preservice teachers to reflect on how culture impacts teaching and learning behaviors. Therefore, preservice teachers will be better prepared to teach all students.

\section{Theoretical Frame Methodology \\ Findings about Question 1 \\ Findings about Question 2 \\ Discussion \\ References}

Many researchers call on teacher educators to embrace a culturally responsive pedagogy in their own teaching practices based on findings of their 
empirical multicultural research (Gay \& Kirkland, 2003; Gunn, 2011; Kleinfeld, 1998; Ladson-Billings, 2000). Illuminating this call are current statistics that describe how White students are still academically outperforming their diverse peers. Based on results of national assessments of reading and mathematics, continued achievement gaps are evident for Black and Hispanic students as compared to White peers (Hemphill \& Vanneman, 2011; Vanneman, Hamilton, Baldwin Anderson, \& Rahman, 2009). Examination of high school graduation rates further demonstrates the significant academic discrepancies across ethnic groups (Chapman, Laird, Ifill, \& KewalRamani, 2011). The Urban Institute's report on ethnic minority graduation rates showed White and Asian American students at $75-77 \%$ and Black and Hispanic students at 50\% (Swanson, 2004). Researchers have presented evidence that culturally responsive pedagogy narrows this gap as culture impacts teaching and learning (Fordham \& Ogbu, 1986; Jordan, 1985; Ladson-Billings, 1995). Therefore, teacher educators should respond by embracing a culturally responsive practice in their own teaching to facilitate the development of preservice teachers' cultural responsiveness.

Eighty to ninety percent of preservice teachers are White, monolingual, young females, from middle class backgrounds in the United States (Lowenstein, 2009; Sleeter, 2001). These demographics contrast with the sociocultural characteristics of our K-12 students. Comparable to preservice teachers, teacher educators also are predominately White females who come from a middle class background (Lowenstein, 2009). Lowenstein (2009) states, "A more complete portrait of the demographic imperative of teacher preparation depicts a majority of white, lower middle class professors who mostly lack urban teaching experiences preparing white, lower middle class female students to be teachers" (p. 170). Therefore, it is imperative that teacher educators not only support and continually develop their own culturally responsive teaching practices, but also model this pedagogy for their preservice teachers. We suggest the utilization of brief "snapshot" autobiographies as one tool for assessing the knowledge and culture of their preservice teachers in order to design instruction that embraces a culturally responsive pedagogy.

The purpose of this manuscript is twofold. First, we propose that teacher educators engage preservice teachers in self-examination through brief written autobiographies as a vehicle for developing a culturally responsive pedagogy. Second, we discuss the use of these snapshot autobiographies as a tool for teacher educators to assess the cultural awareness and needs of their preservice teachers. This study adds to the current literature on culturally responsive research and teaching pedagogy as well as begins to address the call ( $\mathrm{He} \&$ Cooper, 2009) for pedagogical tools that teacher educators can use to foster a culturally responsive pedagogy with preservice teachers.

We first define culture and then address the importance of preservice teachers' understanding of their own culture. Next, we propose that teacher educators address this cultural mismatch by using culturally responsive 
pedagogy within their own practice. Finally, we present reflective writing as one tool to help develop culturally responsive pedagogy with preservice teachers.

\section{Cultural Awareness}

Culture consists of the learned language, beliefs, values, and behaviors infused into every aspect of our lives (Evans \& Gunn, 2011). Banks (2006) more specifically defines culture as the many aspects of a person's identity such as race, religion, language, sexual orientation, gender, and social class (see Figure 1). People associate with or distinguish themselves from one another through these cultural aspects. Although classroom settings often bring together children of diverse ethnicities, religions, and nationalities, the teachers who teach them are overwhelmingly White, female, heterosexual, and from middle class backgrounds (Banks, 2006; Lowenstein, 2009). Zygmunt-Fillwalk and Clark (2007) found that many White, female preservice teachers view culture as a component of membership to a minority group. The preservice teachers in the study identified themselves as not having a culture, but rather as being "American."

While developing understanding of the many dimensions of culture, teachers begin to recognize their own cultural values and beliefs-in essence, their identity. As they begin to reflect upon their complex multidimensional identity, they are better able to see their race, ethnicity, social class, gender, language, religion, and sexual orientation as part of a larger multicultural society (Banks, 1993, 2006). Teachers must develop an awareness and understanding of their own identity before they can understand others (Howard, 2006). This type of reflection contributes to the development of culturally responsive pedagogy.

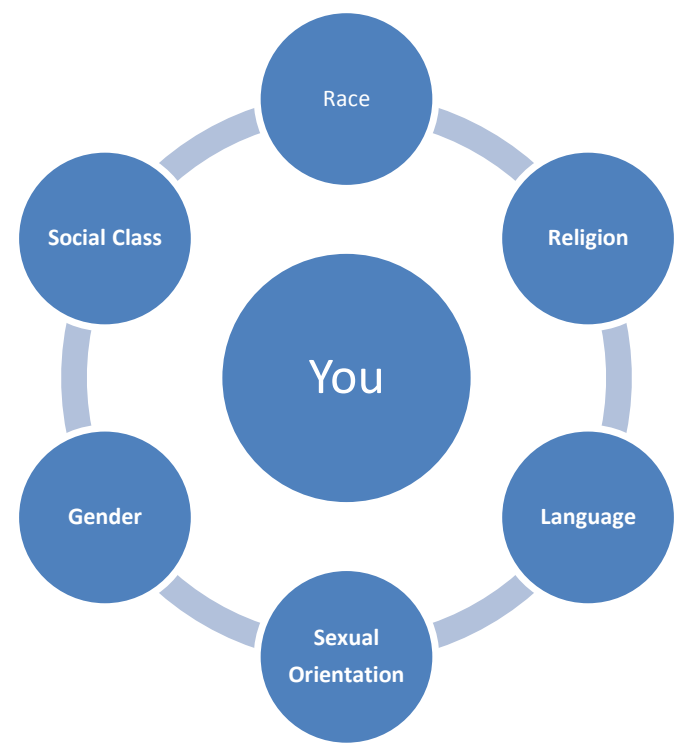

Figure 1. Components of Culture: Different Components that Comprise a Person's Culture as Defined by Banks (2006). 


\section{Cultural Awareness through Self-Reflection}

The development of cultural responsiveness stems from various experiences, as it is multi-dimensional and complex. We believe self-reflection through writing (literacy practices) is an aspect of culturally responsive teaching that needs more exploration. Self-reflection and awareness of one's interpersonal insights are essential to teacher education programs and culturally responsive pedagogy; in order to understand others, individuals must first understand themselves (Howard, 2006; Schmidt, 1999). Some scholars encourage critical self-reflection and analysis to further generate sociocultural consciousness (Gay \& Kirkland, 2003; Ladson-Billings, 2000; Villegas \& Lucas, 2002), and others emphasize cognitive dissonance as a way to promote increased understandings (Lea \& Sims, 2008; McFalls \& Cobb-Roberts, 2001). Teachers' unconscious understandings, such as biases and prejudices regarding students from diverse backgrounds, impact their beliefs and teaching practices (Berlak, 2008).

Essential to becoming a culturally responsive teacher is awareness of differentness of self and others and relatedness to other people and cultures (Howard, 2006). Preservice teachers need to know what the differences are and how they connect to others. As educators and researchers, we need to find ways to facilitate deeper reflections and to better prepare preservice teachers in a time-efficient manner (Adams, Bondy, \& Kuhel, 2005; Fecho, 2000).

Written reflection can serve as a tool to gain individuals' knowledge of self and others, and through their own self-awareness individuals recognize connections to and differentness from others. In recognition of differences and connections, teachers must respect the values and beliefs of others. Written language provides one channel for individuals to explore the self and others. Preservice teachers' reflections illustrate social/emotional connections and personal growth, and reflections can provide further insight into the development of culturally relevant teachers (Morton \& Bennett, 2010). Reflection is a means to examine cognitive dissonance and change. Additionally, reflection provides a way to achieve better understanding of students' cultures and the significance of linking family, home, culture, and learning (Vogt \& Au, 1995). However, teacher educators must model the process, ask the right questions, facilitate deeper discussions, and present more in-depth prompts (Adams et al., 2005; Allen \& Hermann-Wilmarth, 2004; Fecho, 2000; Morton \& Bennett, 2010).

\section{Theoretical Frame}

Mezirow's (1997, 2000) Transformative Learning Theory guided our inquiry. According to Mezirow, transformation occurs through critical reflection and discourse in a safe and comfortable environment. Mezirow (1997) suggests that the process of change occurs around a frame of reference based on assumptions developed through life experiences. Teachers' experiences shape 
their beliefs and values, which impact how they identify their own bias, as well as how these values and beliefs affect others in the classroom (Hale, Snow-Gerono, \& Morales, 2008). Therefore, adults' behaviors, perceptions, expectations, feelings, and attitudes are shaped by experiences. In our study, preservice teachers' discourse of critical reflection occurs through their written autobiographies and conversations with each other and their instructor.

Critical reflection is an ongoing process in educators' beliefs and practices and includes questioning behaviors, beliefs, and values (Powell, Zehm, \& Garcia, 1996). Individuals construct new knowledge through self-discovery and reflection (Ukpokodu, 2003). Teachers improve instruction and understand their teaching better through reflection in three areas: instructional content, students and their learning, and environment and social context of teaching (Zeichner \& Liston, 1996). This critical reflection is essential for the application of culturally responsive pedagogy in classrooms with diverse learners.

Research suggests preservice teachers must reflect critically about experiences with students from diverse ethnic, linguistic, and cultural backgrounds (Adams et al., 2005; Sleeter, 2001). Preservice teachers transform when they negotiate meaning and understanding of their experiences and values through discourse and critical reflection (Mezirow, 1997). After the transformational learning occurs, preservice teachers begin to teach while critically reflecting on their actions.

\section{Writing as a Tool for Cultural Awareness}

Preservice teachers' beliefs and experiences influence their instruction and learning (Berry, 2006; Norman \& Spencer, 2005). In order to make explicit the experiences that shape their beliefs, Norman and Spencer (2005) asked preservice teachers to write an autobiography, and through this self-examination preservice teachers developed self-awareness to facilitate their transformation to more culturally responsive teachers. The preservice teachers in the study stated that these experiences were personal and creative and consequently more meaningful. The researchers concluded that if teacher educators first know preservice teachers' beliefs and understandings, they will be better able to design course content and field experiences to facilitate preservice teachers' connections of writing research and practice (Chambless \& Bass, 1995; Norman \& Spencer, 2005).

Some teacher educators have asked preservice teachers to write autobiographies and biographies about their students or community members in order to recognize similarities and differences and to develop better understandings about people from backgrounds different from their own ( $\mathrm{He} \&$ Cooper, 2009; Leftwich \& Madden, 2006; Pattnaik 2006; Schmidt \& Finkbeiner, 2006; Wake \& Modla, 2008). Pattnaik (2006) and Schmidt and Izzo (2003) asked their preservice teachers to write an autobiography and then a biography of someone from a culture different from their own culture. This exercise helped 
preservice teachers explore their own lived experiences and beliefs as they held them up to the mirror of another's experiences and beliefs.

Culturally responsive pedagogy consists of areas hard to measure: selfawareness, attitudes, beliefs, and perceptions (Hedrick, McGee, \& Mittag, 2000). Writing helps make the invisible visible. In Schmidt and Finkbeiner's (2006) $A B C$ 's of Cultural Understanding and Communication, preservice teachers first write an autobiography and then interview someone from a different cultural background and write a biography about that person. Subsequently, they compare and contrast the autobiography and biography, analyze differences, and make connections. He and Cooper (2009) and Leftwich and Madden (2006) implemented Schmidt and Finkbeiner's model. In both studies, the participants wrote autobiographies, and then each interviewed someone from a different cultural background and wrote a biography of that person. Leftwich and Madden (2006) implemented this model with their own practice as teacher educators to investigate the usefulness of the model for literacy instruction and diversity issues and to examine their students' experiences. The researchers discovered that the autobiographies provided opportunities to self-reflect, which facilitated conversations and think-out-loud reflective practices. He and Cooper (2009) implemented this model in a mixed methods study within two courses of a preservice teacher education program. The results of this study illustrated how using autobiographies can prompt preservice teachers to reflect on "not only ... who they are, but also who they are in relationship with others and who they are as professionals in the teaching field" (p. 317).

Through writing, individuals think and understand the significance of reflection, critical questioning, and seeing the other. For teachers "to become more transformative individuals, they must make a radical shift and reflect on how their values, beliefs, biases, and experiences influence and guide the work they do with students" (Hale et al., 2008, p. 1424). Once this shift occurs, teachers may then develop an increased self-awareness. Writing, and more specifically autobiographies, can be used with preservice teachers on their journey toward developing a culturally responsive pedagogy.

The current study was guided by two overarching questions:

1. What can be learned from a study of preservice teachers' brief autobiographies?

2. How can brief autobiographies assist teacher educators in the development of course content and culturally responsive preservice teachers?

\section{Methodology}

We chose a qualitative design because we wanted to examine how life experiences influenced the preservice teachers' understandings and perspectives (Denzin \& Lincoln, 2005; Fraenkel \& Wallen, 2003). In particular, 
we utilized a case study approach to answer our research questions and illuminate our findings (Yin, 2009).

\section{Positionality of Researchers}

Positionality statements are included on the first three authors, because they are the researchers who coded, transcribed, analyzed, and synthesized the data from this study. The fourth and fifth authors worked with the first three authors to conceptualize, edit, and revise the manuscript.

The first three researchers/authors are all teacher educators at different universities in the southeastern United States. They hold expertise in the areas of literacy and multicultural education, teach in initial certification programs, and prepare preservice teachers to teach in classrooms with diverse learners. They are White women from middle class backgrounds. The authors are culturally similar to the preservice teacher population with whom they work.

The researchers' life experiences have facilitated their decisions to advocate and support social justice issues within education. For example, they have all worked in K-12 schools with students from diverse socioeconomic, linguistic, and cultural backgrounds and witnessed vast inequities. The first author is also the instructor of the class used for this case study. With the other two authors, she discussed these issues and, as she taught preservice teachers, she began to view their and her own experiences through a different lens, becoming more aware of the transformative process she had experienced as a young, White classroom teacher from a middle class background. As a teacher educator, the instructor recognized the necessity to incorporate multicultural education into all of her courses to better prepare preservice teachers to work effectively with all of their future students. Through exploration of preservice teachers' critical reflections, the instructor queried her own notions of race and diversity as a teacher of diverse learners, as well as from the perspective of preservice teachers.

\section{Participants and Course}

Participants in this study included preservice teachers $(N=24)$ who were enrolled in their second internship at a large southeastern university, as well as the instructor of the course. For their internships, each preservice teacher was placed for two days a week in a single grade level classroom, between kindergarten and fifth grade. Additionally, they met for an accompanying seminar one day per week for three hours. The first author of this manuscript was the instructor of the seminar and supervisor of the internships. The preservice teachers' autobiographies were collected during the first seminar meeting. The instructor of the course (first author) was interviewed by the second author at the end of the semester to better understand her experiences as she used information gathered from the brief autobiographies to structure and design 
course content. The second author used a semi-structured interview format (Kvale \& Brinkmann, 2009) and an interview protocol while conducting the interview.

\section{Procedure}

The first seminar meeting took place prior to the preservice teachers' first visits to their respective placements. During this meeting, preservice teachers were introduced to the instructor, syllabus, and the two schools where they would be placed. The preservice teachers then looked at the demographic information for both schools. School A was a Title 1 school with $79 \%$ of students on free and reduced lunch. Sixty to seventy percent of the students at School A spoke English as a second language. School B's population contrasted sharply with that of School A. Twenty-two percent of the students received free and reduced lunch, and seven percent spoke English as a second language. In the initial seminar, the preservice teachers were shown a visual of the different elements (Figure 1) that comprise one's culture and then, together with their instructor, engaged in discourse about culture.

The instructor of the course demonstrated her own reflexivity and provided examples of cultural elements by sharing reflections on her own culture and background. She spoke to each element of culture shown on Figure 1 and gave other examples to encourage diverse answers and a sense of openness in the discourse.

Finally, the preservice teachers were asked to write a 10-minute autobiography about their own culture, why they chose to become an elementary educator, and how they felt about working with children from diverse backgrounds. This 10-minute timeframe was chosen to give the instructor a "snapshot" look into each of preservice teachers' lives and reasons for choosing education as a field of study. This brief timeframe was also chosen so that the instructor could quickly and efficiently gather information that would be used to design instruction that could meet the needs of the preservice teachers. The preservice teachers were told that they only needed to answer and discuss those parts of the assignment that they felt comfortable sharing. The instructor of the course then read their autobiographies and replied to each preservice teacher with reflection questions to provide the preservice teacher an opportunity for a deeper self-reflection.

\section{Data Analysis}

Data sources included: (a) the preservice teachers' autobiographies $(N=$ $24)$, and (b) an interview with the instructor of this course. All $(N=24)$ of the preservice teachers' autobiographies were included in the analysis. The average length of the autobiographies was approximately one handwritten page with a mean of 172 words and a range of 101-281words. To maintain the confidentiality 
of the preservice teachers, the researchers initially removed the names and numbered the autobiographies. The written documents were then individually entered into the Atlas.ti qualitative data analysis software program.

The second author transcribed the interview and subsequently coded and identified initial themes (Strauss \& Corbin, 1990). Each researcher read through the data individually, then met to compare initial analysis and emerging themes, thereby increasing the credibility and dependability of the analysis (Anfara, Brown, \& Mangione, 2002). All researchers coded independently, and codes were compared, resulting in a $92 \%$ intercoder reliability rate. We then printed the data by initial codes and sorted until further themes emerged and collapsed.

\section{Findings about Research Question 1: What Can Be Learned from a Study of Preservice Teachers' Brief Autobiographies?}

In the first seminar meeting, the preservice teachers discussed Banks' (2006) definition of culture and the instructor's insights into her culture. Subsequently, preservice teachers were asked to write a 10-minute autobiography describing their own culture and how they felt about embarking upon their Level 2 internship. Preservice teachers were encouraged to write about all or any elements of their culture they were comfortable discussing. This assignment and the discourse surrounding it provided insights about preservice teachers' understandings of their culture, as well as perspectives on why they chose to begin studying to become a teacher.

\section{Culture}

For their brief autobiographies, the preservice teachers were asked specifically to consider Banks' (2006) definition of culture, which includes many aspects of a person's identity such as race, religion, language, sexual orientation, gender, and social class, and then reflect and write about their own culture. Table 1 portrays Banks' cultural elements and the cultural groups with which preservice self-identified within their brief autobiographies.

While many of the preservice teachers wrote about some components of their culture, none of the preservice teachers discussed their sexuality. The element of culture that was most mentioned in their writings was religion. Seven of the preservice teachers identified with Christianity, one preservice teacher identified with a multi-religious background, and 14 did not mention religion or faith. An example from one autobiography follows:

My family is very tied to our local church. My father was a pastor before I was born and now leads music at his brother's church where my mother attends also. My sister and I attend another church in Largo and are both 
fully involved with music ministries and Youth ministry. This has been a great influence on my love for children and desire to teach.

My biggest struggle for sure if I were to teach in a public school would be not sharing my faith. I don't consider myself someone who forces their beliefs on others, but I am apt to talk about it.

The preservice teachers discussed other elements of culture, but none as much as religion and socioeconomic level (SES). While two preservice teachers implied that they came from a lower SES background, eight associated themselves with a mid- to higher-level SES. In all cases, the interns stated that their families' economic status impacted and influenced their lives. Two examples follow:

My parents are blue-collar workers and are Christian. This has influenced me economically and culturally.

The neighborhood I lived in was an upper middle class neighborhood, very family oriented safe and enjoyable.

Table 1

Numbers of Preservice Teachers Self-identifying Elements of Culture Within Their Autobiographies

Element of Culture/Cultural Group Identified in Autobiographies
Number of Preservice

Teachers (PST) Self-Identified

$(N=24)$

Socioeconomic Status (SES) Level

Low SES background

Mid-to-high SES background

Both low and mid-to-high SES levels

2

8

1

Religion

Christianity

Multi-religious background

7

1

0

Race

Multi-racial

Asian American

Caucasian

2

1

1

Gender

Female

2

Language

English

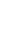

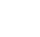




\section{Working with Diversity}

The preservice teachers were asked to reflect on their feelings about working with a diverse population. Diversity was not defined for the preservice teachers; however, the 17 preservice teachers who commented on this topic illustrated the definition of diversity as being ethnically or linguistically different from themselves. The preservice teachers who commented on this topic expressed a dichotomy of emotions about working with a diverse group of students. Preservice teachers alluded to either excitement or apprehension about working with students from diverse backgrounds, but the majority (10) expressed apprehension.

I have mixed feelings about working with children that are different than me. I get nervous because I want to make sure that I am offering them the best opportunities...

My dream is to work in a Title 1 school so that I can be a positive influence where it really counts. I have a heart for helping others, especially children.

(Intern speaks of past experience) I was not nervous going into the school but after the first day there I was panicking. The teacher spoke in black vernacular to the students and her form of classroom management was to literally scream over the loud students. She was going to "call their mamas" or "put them out" if they did not behave. I was scared out of my mind.

\section{Career Choice}

When the preservice teachers were asked why they picked elementary education as a career choice, 13 of the 24 preservice teachers responded that they always loved children. The preservice teachers used the autobiography as a space to share an experience or elaborate on why they enjoy children.

I always knew I wanted to be a teacher, I love working with children. I love working with children and have worked with children as a nanny for 5 years.

While the preservice teachers made connections to the love of children, or childhood memories, only two interns related their career choice in education to an understanding of educational pedagogy, children's learning, or teaching methods.

I always knew I wanted to work with children so I decided to either become a pediatric nurse or a teacher. In HS I took on nursing for 3 years and got my CNA license. My senior year I decided to be a kindergarten aide and that's when I knew I was meant to be a teacher. I absolutely loved every single day that I spent in the classroom with those kids. 


\section{Findings about Question 2: \\ How Can Brief Autobiographies Assist \\ Teacher Educators in the Development of Course Content and Culturally Responsive Preservice Teachers?}

At the end of the semester, the instructor of the course (first author) was interviewed by the second author about the use of brief autobiographies with preservice teachers. The instructor used the autobiographies as a tool for developing course content that could more effectively lead the preservice teachers in the study on a journey of self-reflection and ultimately the development of a culturally responsive pedagogy. When asked why she used autobiographies as a pedagogical tool, the instructor stated, "I wanted to find a way for my preservice teachers to explore their own identity and their culture.... kept hearing the words, when I deal with 'those' children; 'when I deal with the other children." She further stated that the preservice teachers saw ethnicity and language as barriers instead of searching for ways to explore how to teach all children.

\section{Reflection}

The instructor used a figure (see Figure 1) to visually represent the different elements that comprise culture (Banks, 2006). By doing so, she felt that the preservice teachers were able to recognize culture as "...this spectrum, this grand idea made of different components and to see where you fit into all these different areas of race, ethnicity, gender, religion, language, sexuality...you begin to see that your culture is composed of many components."

The instructor also elaborated that use of autobiographies gave preservice teachers the time to process their own thoughts about their culture. "There's something to storytelling and the written word...taking the time to think, then process, and write it to really explore your metacognition of who you are." The preservice teachers suggested different aspects of culture impacted their lives such as socioeconomic status, religion, and ethnicity.

\section{Connectiveness}

The instructor felt that the autobiographies were a way for the preservice teachers to see a connection to other people by referring to the different components of culture.

You might...you might have this White culture, but then you see you are not only White, but White, Italian, Presbyterian, second language learner, homosexual... all these different areas. So different areas of someone's 
culture relates to someone else's. So we, we learn about different similarities and differences of our students.

When asked if there were any surprises to her findings from the snapshot autobiographies, the instructor focused on what was discussed and what was not: "I was not surprised with how many students identified with religion, but rather how strongly they spoke of their religion." She also stated,

Another surprise to me might be sexuality....No one identified themselves as a homosexual, heterosexual, or bisexual; they just skipped it. I had one student who wrote in the autobiography 'sexuality' and then she wrote the word "really" and a question mark. I felt like she couldn't even believe I was discussing these issues.

\section{Future Use}

When discussing the use of this assignment in the future, the instructor believed the preservice teachers' initial autobiographies could be used as a tool to connect future assignments with preservice teachers learning about different cultures, as well as a starting point to look at culture.

I really think that looking further into how to really develop it more would benefit...and for me as an instructor, to guide them through this process. So it's not just self-exploration, but a guidance of "What does this do for my teaching? What does this mean for the students I teach?"

The instructor observed that after reading her preservice teachers' autobiographies, she could then think about course content and how to align it to her students' current understandings of their personal culture: "We have to start with understanding our own culture and the components of it."

The instructor further elaborated on this assignment and considered it a stepping-stone to other course content as a way of bridging culture with classroom teaching. Through this assignment, she could guide preservice teachers to explore, "How does my culture influence how I teach?" and "What does this mean for the students that I teach?" She maintained that the autobiography should not be just a "one-time assignment." The second author/interviewer agreed and further suggested the preservice teachers could "work on their own autobiography, but then they work on a biography of someone else in the class." The instructor followed with the idea that preservice teachers could interview families in the communities.

\section{Pedagogical Tool}

As a pedagogical tool for developing a culturally responsive pedagogy, the instructor stated that this assignment was a "great starting point to embark on a journey of learning about culture, your own culture, and your cultural identity." The instructor made culturally responsive decisions in response to the preservice 
teachers' autobiographies. Based upon the readings of the autobiographies, the instructor purposefully selected which of the two schools the preservice teachers would be assigned to for their internship. The instructor wanted to provide the preservice teachers with a different school setting than they had experienced in their first internship. The instructor also purposefully selected guest speakers to foster dialogue about culturally responsive issues that the instructor deemed important from reading the autobiographies.

One of the guest speakers talked about free and reduced lunch status. I thought it was important for the preservice teachers to understand what being eligible for free and reduced lunch could mean for a child. Many of the preservice teachers did not identify with poverty, and I thought that would be important.

The instructor saw autobiographies as "powerful tool[s] in the students' exploration of their cultural identity." The second author/interviewer agreed, observing that the autobiographies enhanced the students' abilities to share their voices.

\section{Discussion}

We collected and analyzed preservice teachers' 10-minute autobiographies to learn more about the use of autobiographies as a channel for assessing preservice teachers' self-perceptions and cultural awareness. The instructor utilized this quick pedagogical tool to then develop course content that could lead to further facilitation of culturally responsive pedagogy with preservice teachers. The preservice teachers wrote specifically about (a) their culture, (b) their feelings about working with diverse students, and (c) their decisions to choose education as a career. In addition to the 24 preservice teachers' autobiographies, we conducted an interview with the instructor of this course (also the first author of this manuscript). The interview was designed to learn more about the instructor's perceptions of using brief autobiographies as a tool for assessing preservice teachers' cultural awareness in order to develop teacher education course content that might foster their culturally responsive pedagogy. Her thoughts provided insight into how autobiographies might be used for preservice teachers to embark upon a self-exploration of their own culture and how autobiographies might be employed in the future.

The preservice teachers reflected upon the components of their culture they wanted to discuss openly. While approximately one-third of the preservice teachers discussed the role religion plays in their life, none of the preservice teachers reflected on their sexuality. A dichotomy of emotions was expressed by the preservice teachers who commented on working with diverse students. While the majority of preservice teachers expressed fear or apprehension, some students expressed excitement about working with students from diverse backgrounds. All of the preservice teachers in this study expressed a desire to teach children. More than half of these preservice teachers elaborated that their 
desire to become a teacher because of their "love of teaching." Only two of the preservice teachers discussed pedagogical reasons or the importance of educating children. Using Banks' (2006) definition of culture as a guide for our preservice teachers to write about their culture offered us the opportunity to view where our preservice students were on their journey to becoming culturally responsive teachers, and more importantly, how we need to shape our instruction to meet the needs of our preservice teachers. As Howard (2006) stated, reflection is the first step on the path to becoming a culturally responsive teacher.

The instructor of this course stated that using brief autobiographies in the beginning of a semester could be a powerful tool for understanding many elements that comprise a person's culture and for developing an initial understanding of one's culture and connectivity to all people through different parts of his/her culture. While these autobiographies are a starting point for teacher educators as an assessment of where their preservice teachers are on their journey of viewing themselves as cultural beings, the autobiographies also afford novice teachers the opportunity to reflect on their complex multidimensional identities (Banks, 1993, 2006; Evan \& Gunn, 2011; Gunn, 2011). Similar to the findings of Davis, Ramahlo, Beyerbach, and London (2008), the use of autobiographies in this study helped preservice teachers "to think about the complexity of identity formation," as well as assisting the researchers to learn about the backgrounds of the preservice teachers (p. 228).

The instructor of this course discussed how she would then use her initial understandings of the preservice teachers' autobiographies to develop course content that could embrace a culturally responsive pedagogy. These snapshot autobiographies provided information for the instructor to construct additional exercises throughout the semester to guide the preservice teachers in their journey while working in their field experiences. Understanding preservice teachers' current knowledge is essential to taking them on this journey.

\section{Conclusion}

We call for teacher educators to provide experiences for their preservice teachers to reflect upon the connectedness of their prior knowledge and their culture. Teacher educators should provide ample opportunities for preservice teachers to work through this complex process to uncover their self-identity throughout several courses, as well as through guided practice across clinical and fieldwork experiences. We emphasize the importance of this process taking place early and throughout the education program.

Teacher educator reforms have suggested that preservice teachers need to be able to "think pedagogically, reason through dilemmas, investigate problems, and analyze student learning to develop appropriate curriculum for a diverse group of learners" (Darling-Hammond et al., 2005, p. 393). Teacher educators need to supply opportunities for preservice teachers to engage in 
reflection on how culture affects teaching and learning behaviors. We believe that given the demographics of today's schools, preparing preservice teachers to work with diverse populations is a critical component of teacher preparation. Furthermore, we believe that teacher education needs to start this preparation by giving preservice teachers the chance to reflect upon and develop an understanding of their own culture. These types of reflections will prepare preservice teachers to learn how their future students may take advantage of their own experiences as a lens for learning new information (Darling-Hammond et al., 2005; Morton \& Bennett, 2010)

By providing these pedagogical experiences, preservice teachers can then begin to connect their education classroom experiences with their clinical experiences. Through the use of these snapshot autobiographies, teacher educators can ignite the reflective pedagogy of how culture, teaching practices, and self are interconnected between preservice teachers and the students they will serve.

Insights from snapshot autobiographies can assist teacher educators in laying the foundation for courageous conversationsin their classroom about culture, teaching, and learning (Singleton \& Linton, 2006). Although the demographics of teacher educators mirror those of preservice teachers (Lowenstein, 2009), it is imperative that teacher educators cultivate experiences that are responsive to preservice teachers' strengths and needs. Snapshot autobiographies are an efficient tool that provides information teacher educators can use to develop and scaffold experiences to foster preservice teachers' culturally responsive pedagogy.

\section{References}

Adams, A., Bondy, E., \& Kuhel, K. (2005). Preservice teacher learning in an unfamiliar setting. Teacher Education Quarterly, 32(2), 41-64. Retrieved from http://www.teqjournal.org/

Allen, J., \& Hermann-Wilmarth, J. (2004). Cultural construction zones. Journal of Teacher Education, 55, 214-226. doi:10.1177/0022487104263540

Anfara, V. A., Brown, K. M., \& Mangione, T. L. (2002). Qualitative analysis on stage: Making the research process more public. Educational Researcher, 31(7), 28-38. doi:10.3102/0013189X031007028

Banks, J. A. (1993). Multicultural education: Characteristics and goals. In J. A. Banks \& C. A. Banks (Eds.), Multicultural education issues and perspectives (pp. 3-28). Needham Heights, MA: Simon \& Schuster, Inc.

Banks, J. A. (2006). Race, culture, and education: The selected works of James A. Banks. London, UK: Routledge.

Berlak, A. (2008). Challenging the hegemony of whiteness by addressing the adaptive unconscious. In V. Lea \& E. J. Sims (Eds.), Undoing whiteness in 
the classroom: Critical educultural teaching approaches for social justice activism (pp. 47-66). New York, NY: Peter Lang Publishing, Inc.

Berry, R. A. (2006). Beyond strategies: Teacher beliefs and writing instruction in two primary inclusion classrooms. Journal of Learning Disabilities, 39(1), 11-24. doi:10.1177/00222194060390010301

Chambless, M. S., \& Bass, J. F. (1995). Effecting changes in student teachers' attitudes toward writing. Reading Research and Instruction, 35, 153-159. doi:10.1080/19388079509558204

Chapman, C., Laird, J., Ifill, N., \& KewalRamani, A. (2011). Trends in high school dropout and completion rates in the United States: 1972-2009 (NCES 2012-006). Washington, DC: National Center for Education Statistics, US Department of Education. Retrieved from http://nces.ed.gov/pubsearch/ pubsinfo. asp?pubid=2012006

Darling-Hammond, L., Hammerness, K., Grossman, P., Rust, F., \& Shulman, L. (2005). The design of teacher education programs. In L. DarlingHammond \& J. Bransford (Eds.), Preparing teachers for a changing world: What teachers should learn and be able to do (pp. 390-441). San Francisco, CA: Jossey-Bass.

Denzin, N. K., \& Lincoln, Y. S. (2005). Introduction: The discipline and practice of qualitative research. In N. K. Denzin \& Y. S. Lincoln (Eds.), The Sage handbook of qualitative research (3rd ed., pp. 1-32). Thousand Oaks, CA: Sage Publications, Inc.

Davis, R. D., Ramahlo, T., Beyerbach, B., \& London, A. P. (2008). A culturally relevant teaching course: Reflecting preservice teachers' thinking. Teaching Education, 19(3), 223-234. doi:10.1080/10476210802250265

Evans, L. S., \& Gunn, A. A. (2011). It's not just the language: Culture as an essential component in preservice teacher education. Journal of Multiculturalism in Education, 7(1). Retrieved from http://www.wtamu.edu/ journal/multiculturalism-in-education.aspx

Fordham, S., \& Ogbu, J. (1986). Black students' success: Coping with the "burden of 'acting "White." Urban Review, 18, 1-31.

Fecho, B. (2000). Developing critical mass: Teacher education and critical inquiry pedagogy. Journal of Teacher Education, 51(3), 194-199. doi:10.1177/00 22487100051003006

Fraenkel, J. R., \& Wallen, N. E. (2003). How to design and evaluate research in education (5th ed.). New York, NY: McGraw-Hill Publishers.

Gay, G., \& Kirkland, K. (2003). Developing cultural critical consciousness and self-reflection in preservice teacher education. Theory Into Practice, 42, 181-187. doi:10.1207/s15430421tip4203_3

Gunn, A. A. (2011). Developing a culturally responsive literacy pedagogy: Preservice teachers, teaching cases, and postcard narratives. (Doctoral 
Dissertation). Retrieved from Proquest Dissertation and Theses Database. (AAT3432801).

Hale, A., Snow-Gerono, J., \& Morales, F. (2008). Transformative education for culturally diverse learners through narrative and ethnography. Teaching and Teacher Education, 24, 1413-1425. doi:10.1016/j.tate.2007.11.013

He, Y., \& Cooper, J. E. (2009). The ABCs of preservice teacher cultural competency development. Teaching and Teacher Education, 20(3), 305322. doi:10.1080/10476210902943256

Hemphill, F. C., \& Vanneman, A. (2011). Achievement Gaps: How Hispanic and White students in public schools perform in mathematics and reading on the National Assessment of Educational Progress (NCES 2011-459). Washington, DC: National Center for Education Statistics, Institute of Education Sciences, U.S. Department of Education. Retrieved from http://nces.ed.gov/nationsreportcard/pubs/studies/2011459.asp

Hedrick, W. B., McGee, P., \& Mittag, K. (2000). Pre-service teacher learning through one-on-one tutoring: Reporting perceptions through e-mail. Teaching and Teacher Education, 16, 47-63. Retrieved from http://www.journals.elsevier.com/teaching-and-teacher-education/

Howard, G. R. (2006). We can't teach what we don't know: White teachers, multiracial schools (2nd ed.). New York, NY: Teachers College Press.

Jordan, C. (1985). Translating culture: From ethnographic information to educational program. Anthropology \& Education Quarterly, 16(2), 105123.

Kleinfeld, J. (1998). The use of case studies in preparing teachers of cultural diversity. Theory Into Practice, 37(2), 140-147. doi: 10.1080/00405849809 543797

Kvale, S., \& Brinkmann, S. (2009). Interviews. Thousand Oaks, CA: Sage Publications, Inc.

Ladson-Billings, G. (1995). Toward a theory of culturally relevant pedagogy. American Educational Research Journal, 32, 465-491. doi:10.3102/00028 312032003465

Ladson-Billings, G. (2000). Fighting for our lives: Preparing teachers to teach African American students. Journal of Teacher Education, 51(3), 206-214. doi: $10.1177 / 0022487100051003008$

Lea, V., \& Sims, E. J. (2008). Introduction: Undoing Whiteness in the classroom: Different origins, shared commitment. In V. Lea \& E. J. Sims (Eds.), Undoing Whiteness in the classroom: Critical educultural teaching approaches for social justice activism (pp. 1-28). New York, NY: Peter Lang Publishing.

Leftwich, S., \& Madden, M. (2006). Doing the ABC's: An introspective look at process. In R. R. Schmidt \& C. Finkbeiner (Eds.), ABC's of cultural 
understandings and communication: National and international adaptations (pp. 73-92). Greenwich, CT: Information Age Publishing.

Lowenstein, K. L. (2009). The work of multicultural teacher education: Reconceptualizing white teacher candidates as learners. Review of Educational Research, 97(1), 163-196. doi:10.3102/0034654308326161

McFalls, E. L., \& Cobb-Roberts, D. (2001). Reducing resistance to diversity through cognitive dissonance instruction: Implications for teacher education. Journal of Teacher Education, 52(2), 164-172. doi:10.1177/002 2487101052002007

Mezirow, J. (1997). Transformative learning: Theory to practice. New Directions for Adult and Continuing Education, 74, 5-12. doi:10.1002/ace.7401

Mezirow, J. (2000). Learning as transformation: Critical perspectives on a theory in progress. San Francisco, CA: Jossey-Bass.

Morton, M. L., \& Bennett, S. V. (2010). Scaffolding culturally relevant pedagogy: Preservice teachers in an urban university/school collaboration. Journal of Ethnographic and Qualitative Research, 4(3), 139-150. Retrieved from http://www.cedarville.edu/event/eqrc/journal/journal.htm

Norman, K. A., \& Spencer, B.H. (2005). Our lives as writers: Examining preservice teachers' experiences and beliefs about the nature of writing and writing instruction. Teacher Education Quarterly, 32(1), 23-40. Retrieved from http://www.teqjournal.org/

Pattnaik, J. (2006). Revealing and revisiting "self" in relation to the culturally different "other": Multicultural teacher education and the ABC's model. In R. R. Schmidt \& C. Finkbeiner (Eds.), ABC's of cultural understandings and communication: National and international adaptations (pp. 111-141). Greenwich, CT: Information Age Publishing.

Powell, R. R., Zehm, S., \& Garcia, J. (1996). Field experience strategies for exploring diversity in schools. Englewood Cliffs, NJ: Prentice-Hall.

Schmidt, P. R. (1999). Focus on research: Know thyself and understand others. Language Arts, 76, 332-340. Retrieved from http://www.ncte.org/ journals/la

Schmidt, P. R., \& Finkbeiner, C. (Eds.). (2006). ABC's of cultural understanding and communication: National and international adaptations. Greenwich, CT: Information Age Publishing.

Schmidt, P. R., \& Izzo, A. (2003, January). Home/school communication for literacy development. Paper presented at the Educational Research Conference, Honolulu, Hawaii. Retrieved from ERIC database. (ED 473480).

Singleton, G. L., \& Linton, C. W. (2006). Courageous conversations about race: A field guide for achieving equity in schools. Thousand Oaks, CA: Corwin Press. 
Sleeter, C. E. (2001). Preparing teachers for culturally diverse schools: Research and the overwhelming presence of whiteness. Journal of Teacher Education, 52, 94-106. doi:10.1177/0022487101052002002

Strauss, A., \& Corbin, J. (1990). Basics of qualitative research: Grounded theory procedures and techniques. Newbury Park, CA: Sage Publications, Inc.

Swanson, C. (2004). Who graduates? Who doesn't? A statistical portrait of public high school graduation, class of 2001. Washington, DC: The Urban Institute Education Policy Center. Retrieved from http://www.urban.org/ publications/410934.html

Ukpokodu, O. N. (2003). Teaching multicultural education from a critical perspective: Challenges and dilemmas. Multicultural Perspectives, 5(4), 17-23. doi:10.1207/S15327892MCP0504_4

Vanneman, A., Hamilton, L., Baldwin Anderson, J., \& Rahman, T. (2009). Achievement gaps: How Black and White students in public schools perform in mathematics and reading on the National Assessment of Educational Progress (NCES 2009-455). Washington, DC: National Center for Education Statistics, Institute of Education Sciences, U.S. Department of Education. Retrieved from http://nces.ed.gov/nations reportcard/pubs/studies/2009455.asp

Villegas, A. M., \& Lucas, T. (2002). Preparing culturally responsive teachers. Journal of Teacher Education, 53, 20-32. doi:10.1177/002248710205 3001003

Vogt, L. A., \& Au, K. H. P. (1995). The role of teachers' guided reflection in effective positive program change. Bilingual Research Journal, 19(1), 101120.

Wake, D. G., \& Modla, V. B. (2008). Using multicultural literature to teach culturally responsive instructional approaches. In M. Foote, F. Falk-Ross, S. Szabo, \& M. B. Sampson (Eds.), Navigating the literacy waters: Research, praxis, \& advocacy (pp. 179-200). The Twenty-Ninth Yearbook of the College Reading Association Logan, UT: College Reading Association.

Yin, R. K. (2009). Case study research: Design and methods. Thousand Oaks, CA: Sage Publications, Inc.

Zeichner, K. M., \& Liston, D. P. (1996). Reflective teaching: An introduction. Mahwah, NJ: Lawrence Erlbaum Associates.

Zygmunt-Fillwalk, E., \& Clark, P. (2007). Becoming multicultural: Raising awareness and supporting change in teacher education. Childhood Education, 83(5), 288-293. doi:10.1080/00094056.2007.10522934 